\title{
Demand for Egyptian Molasses in the World Market: a Panel Estimation
}

\author{
Mohamed Altabei Alboghdady* \\ Agricultural Economics Department, Faculty of Agriculture, Suez Canal University
}

Received: $15 / 10 / 2015$

\begin{abstract}
Although Egypt is considered one of the most important export countries for molasses in the world market, Egyptian molasses export witnessed notable fluctuations during the last decade. Nevertheless, there is almost no study investigates and estimates the factors affecting its demand in the world market. The present study aims mainly toestimate demand function of the Egyptian molasses in the global market and in each individual importer market. Competitors' relative prices, income of import country, exchange rate of rival exporters, and volatility of relative prices and exchange rate were the proposed determinants of the exported quantity of Egyptian molasses in the global market. Random effects analysis was conducted to estimate the demand function using panel data of three importer countries during the period of 1986-20012. The results showed that Egypt/India price ratio, Egypt/Pakistan exchange rate, and pricesvolatilityare significantly affecting negativelythe Egyptian molasses exports. The results of the estimation of demand function for each importer country independently showed nearly the same conclusions with minor differences. The responsiveness of Egyptian molasses exports to UK, Italy, and Spain Markets to the price ratios were measured by the price ratios elasticities in each market. The elasticities of Egypt/Pakistan Price ratio showed highest elasticities in UK and Spain markets by $4.85 \%$ and $4.12 \%$, respectively. The Egypt/India price elasticity was the highest in Italy market by -5 .
\end{abstract}

Keywords: Price volatility - Exchange rate - Exports - Im-Pesaran-Shin test (IPS) - Random Effects Model

\section{INTRODUCTION}

Egypt's agriculture is the main pillar upon which ancient Egyptian civilization flourished and has been a vital source of wealth throughout history. Nevertheless, the sectoral growth rate of value added in agriculture was persistently lower than half that of industry and services sectors (Kheir-El-Din, 2008). Despite agriculture played anessential role in boosting Egypt's exports accounted for two-thirds of total exports until the mid-1970 (Al-Santarisi, 1995), the relative importance of Egypt's agricultural exports had dropped dramatically to $33 \%$ in 1987 and $10.4 \%$ during 1995-2003 (Bassyouni, 2009). On the other hand, agricultural imports increased significantly. Such phenomenon leads to chronic deficit in agricultural trade balance. As a result, the agricultural exports/imports ratio was 0.28 in 2005 (Alboghdady, 2007) and increased to 0.31 in 2012. Therefore, the policy of agricultural development is paying an attention to a new export strategy that would allow Egypt to, (i) alter from old strategies of exporting residuals to a new concept that is agriculture for export, and (ii) improving the international competitiveness of the agricultural export sector (World-Bank, 2001).

Molasses is one of the processed agricultural product by which Egypt competes in the global market. Egypt produced about $20 \%$ and exported about $50 \%$ of the African total production and export value, respectively during the period of 2005-2011. With widerinsight, Egypt produced about $1.2 \%$ and exported on average of $8 \%$ of the global molasses market ${ }^{1}$. The major countries compete in molasses world market are Indonesia, Pakistan, Thailand, Egypt, Germany, Guatemala, India, and United States of America. Pakistan, Thailand, India, and USA are the common competitors in the Egyptian molasses demand markets.
Egyptian molasses export witnessed notable oscillations during the last decade as seen in Figure (1). The world market share of Egyptian molasses export value decreased from 44 million US dollar representing $7 \%$ in 2006 to $0.3 \%$ in 2009 and $1.7 \%$ in 2011. Therefore, the present study aims mainly toexamine the main factors affecting Egyptian molasses export in the global market by estimating Egyptian molasses demand function.

\section{METHODOLOGY}

Goldstein and Khan (1978) set out the standard outline for analyzing export demand function at specific market. The main idea of the model specification is as follows:

$X_{t}=\beta_{0}+\beta_{1}\left(\frac{P x_{t}}{P w_{t}}\right)+\beta_{2} Y_{t}$

where, $X_{t}$ is the quantity of export demand at time $\mathrm{t}$, $P x_{t}$ is the price of export at time t, $P w_{t}$ is the export price of competitors, and $Y_{t}$ is the country's real income of the trading partner as the conventional demand theory says that, the consumer is postulated to maximize utility subject to a budget constraint, and $\beta_{0}$ and $\beta_{1}$ are unknown parameters. The model has been extended in such a way to account for real exchange rate and its volatility (Asseery and Peel, 1991; Chowdhury, 1993; Cushman, 1983; Hooper and Kohlhagen, 1978; Kenen and Rodrik, 1986; Serenis and Tsounis, 2012). The model can be summarized by: $X_{t}=\beta_{0}+\beta_{1}\left(\frac{P x_{t}}{P w_{t}}\right)+\beta_{2} Y_{t}+\beta_{3} R_{t}+\beta_{4} R V_{t}+\beta_{5} P V_{t}$

where, $R_{t}$ is exchange rate of Egyptian currency with rivals. $R V_{t}$ is the exchange rate volatility and $V P$ is the volatility of the price ratio of $\left(\frac{P x_{t}}{P w_{t}}\right)$. In terms of cross countries level panel data and flowing (Jin, 2010), the model for competitors $\mathrm{j}$ and imported market i will be:

\footnotetext{
${ }^{1}$ Computed from FAO database, www.faostat.fao.org

*E-mail: mboghd@agr.suez.edu.eg
} 
$X_{t i}=\beta_{0}+\sum_{k=1}^{j}\left(\beta_{0 k}\left(\frac{p_{x t i}}{p_{k t i}}\right)+\beta_{1 k} P V_{k t}+\beta_{2 k} R_{k t}+\right.$

$\left.\beta_{3 k} R V_{k t}\right)+\sum_{n=1}^{i}\left(\beta_{4 i} G D P_{t i}\right)$

According to economic theory, a rise in Egyptian molasses prices would reduce its quantity demanded and subsequently its market share. On the contrary, a rise in competitors' prices may stimulate the importer market to increase the importing of Egyptian molasses. Therefore, the expected signsof the coefficients $\left(\beta_{0 k}\right)$ of the price ratios $\left(\frac{p_{x t i}}{p_{k t i}}\right)$ are negative. Likewise, a rise in Egyptian currency against competitors in specific market may also reduce the demand for the Egyptian molasses in these markets. Thus, the expected signs of the coefficients $\beta_{2 k}$ of exchange rate ratios $R_{k t}$ are negative. Intuitively, the volatility of exchange rate and prices have an inverse effect on exports due to high risk to importers that is why the expected sign of the coefficients of prices $\left(\beta_{1 k}\right)$ and exchange rate $\left(\beta_{3 k}\right)$ are expected to be negative. In contrast, the expect sign of the coefficients of real income of the trading partners are expected to be positive.

Measuring of exchange rate volatility is not directly observable so; there are many techniques of measuring volatility. Most empirical studies have utilized the standard deviation of the moving average (Serenis and Tsounis, 2012). Following Koray and Lastrapes (1989) and Akhtar and Hilton (1984), the volatility measure was calculated as:

$V_{t}=\left[\frac{1}{m} \sum_{i=1}^{m}\left(\log R_{t+i-1}-\log R_{t+i-2}\right)^{2}\right]^{1 / 2}$

where, $V_{t}$ is the volatility and $m$ is the order of moving average which is specified as 3 in the present study.

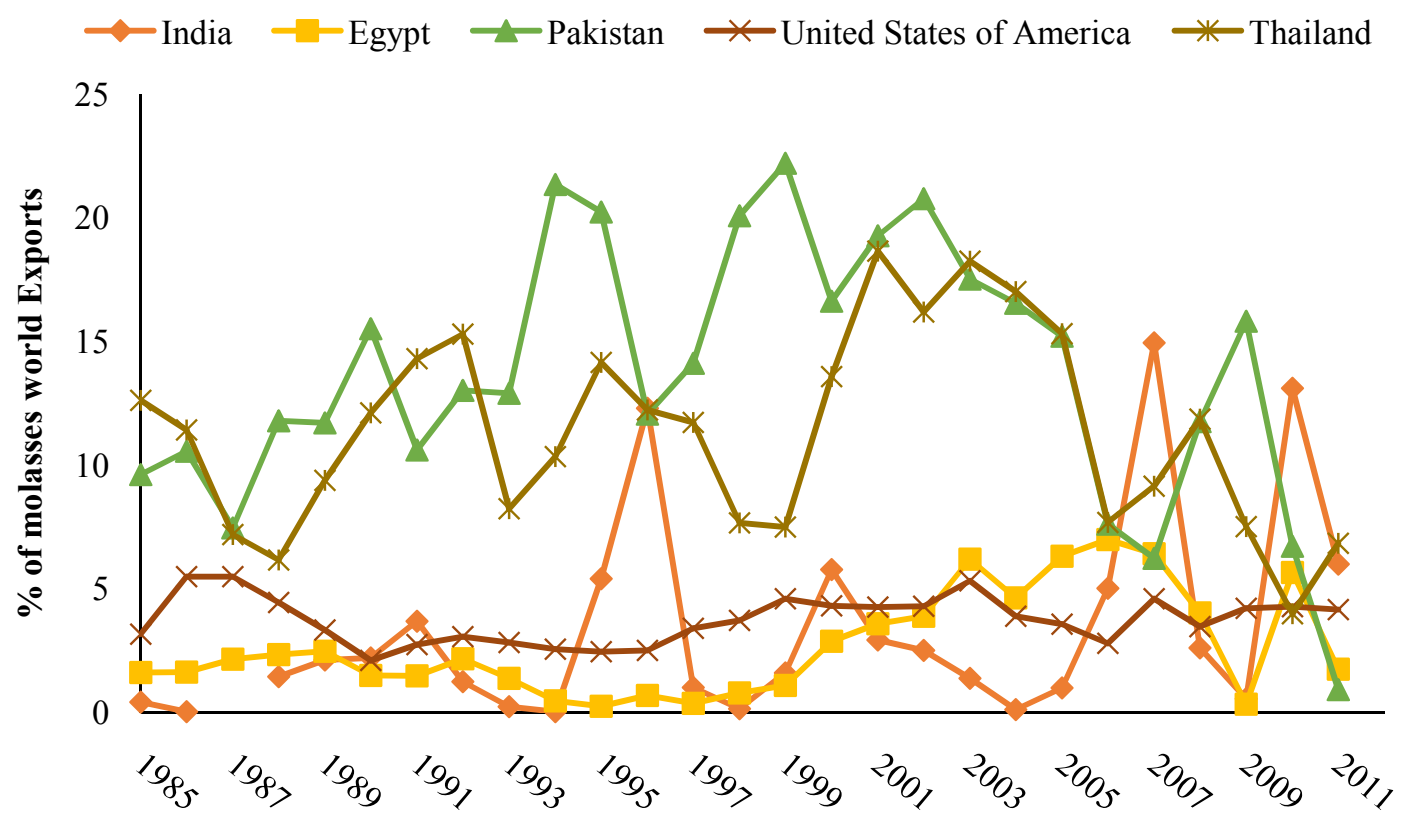

Fig. (1): Market Shares of Molasses Export in the World Market (1986-2012)

\section{Data}

Annual panel data covering the period of 19862012 were used in the current study. Egyptian exports quantities and prices of molasses to target markets and those from competitors are obtained from FAO statistics database. Exchange rates are acquired from Agricultural Exchange Rate Data Set (ERS) United States Department of Agriculture (USDA) Economic Research Service. A summary statistics of all data set are presented in Table (1).

\section{Time series properties}

When dealing with time series, a general problem is non-stationarity with the data. Non-stationary and cointegration may also exist in panel data, which may lead to spurious regressions. There are many tests for unit root or stationarity in panel datasets. Levin et al. (2002), Breitung and Das (2005), Im et al. (2003), and fisher- type Choi (2001) tests have as the null hypothesis that all the panels contain a unit root. Im-Pesaran-Shin (IPS) unit-root test has been adopted because of its several advantages compared with the other mentioned tests: (i) IPS test is not as restrictive as the Levin-Lin-Chu test. (ii) Since it allows for heterogeneous coefficients, the small sample performance of the IPS test is better than Levin-Lin-Chu test.' (iii) It allows unbalanced panels, while most of the remaining tests require balanced panels. The general structure used by most panel unit root testing procedures is:

$\Delta y_{i t}=\rho_{i} y_{i, t-1}+\sum_{i=1}^{p_{i}} \theta_{i, j} \Delta y_{i, t-1}+\beta_{i} d_{i t}+\varepsilon_{i t}$

where, $d_{i t}$ are the deterministic components. $\rho_{i}=0$ means the y process has a unit root for individual $\mathrm{i}$, while $\rho_{i}<0$ means that the process is stationary around the deterministic part. 
Table (1): Summary statistics of export demand function components for Egyptian molasses during the period of (19862012).

\begin{tabular}{lccccc}
\hline Item & Unit & Mean & St. Dev. & Min. & Max. \\
\hline Egyptian molasses exports & 1000 Tons & 201.61 & 143.71 & 19817 & 476826 \\
Egyptian price & US \$ & 98.75 & 35.93 & 52.91 & 175.32 \\
Indian price & US \$ & 86.92 & 65.05 & 38.48 & 345.68 \\
Pakistan price & US \$ & 56.14 & 25.41 & 23.66 & 122.48 \\
Thailand price & US \$ & 57.95 & 23.85 & 27.61 & 129.32 \\
Indian currency Exchange rate & Indian Rupee & 55.65 & 9.90 & 36.38 & 68.42 \\
Pakistan currency Exchange rate & Pakistani Rupee & 84.45 & 13.56 & 62.83 & 113.25 \\
Thailand currency Exchange rate & Thai Baht & 34.84 & 5.65 & 27.40 & 45.91 \\
UK GDP & Billion USD & 1653.90 & 684.28 & 601.93 & 2964.40 \\
Italy GDP & Billion USD & 1428.45 & 504.93 & 631.72 & 2403.21 \\
Spain GDP & Billion USD & 812.75 & 419.26 & 250.68 & 1642.74 \\
\hline
\end{tabular}

Source: FAO statistics database and Agricultural Exchange Rate Data Set (ERS).

The results of unit root test are presented in Table (2). The test was applied for drift and trend models.We could reject the null hypothesis (the series contains a unit root) at the significance level $5 \%$ for molasses price of India, Thailand, and USA. The null hypothesis also could rejected at significance level of $1 \%$ for molasses prices of Egypt and Pakistan. In contrast, we could not reject it for the variables of exchange rates except of Pakistan exchange rate at the first order of difference.
The results of trend model indicated that the null hypothesis was rejected at significance level of 5\% for USA price and at $1 \%$ for Egypt, India, Pakistan, and Thailand prices. Instead, a unit root has been detected in exchange rate prices. As a result, the differencing was conducted to induce stationary. An i (1) was required for Pakistan exchange rate, i (2) for India exchange rate, and i (3) for Thailand and USA exchange rates.

Table (2): Results of Im-Pesaran-Shin unit root test

\begin{tabular}{|c|c|c|c|c|}
\hline \multirow{2}{*}{ Variables } & \multicolumn{2}{|c|}{ Drift } & \multicolumn{2}{|c|}{ Trend } \\
\hline & Statistic & Lags & Statistic & Lags \\
\hline Egypt Molasses Export Price & $\begin{array}{c}-3.6114 \\
(0.0005)^{* *}\end{array}$ & 0 & ${ }^{-3.6114}{ }^{*}(0.0005)^{* *}$ & 0 \\
\hline India Molasses Export Price & $\begin{array}{c}-3.2497 \\
(0.0298)^{*}\end{array}$ & 0 & ${ }^{-3.8699}$ & 0 \\
\hline Pakistan Molasses Export Price & $\begin{array}{c}-3.5213 \\
(0.0006)^{* *}\end{array}$ & 0 & ${ }^{-3.5213}$ & 0 \\
\hline Thailand Molasses Export Price & $\begin{array}{c}-2.7290 \\
(0.0185)^{*}\end{array}$ & 0 & ${ }^{-3.0050}$ & 0 \\
\hline U.S.A Molasses Export Price & $\begin{array}{c}-3.2542 \\
(0.0176)^{*}\end{array}$ & 0 & $\begin{array}{c}-3.2622 \\
(0.0400)^{*}\end{array}$ & 0 \\
\hline Egypt-India Exchange Rate & $\begin{array}{l}-0.2419 \\
(0.4044)\end{array}$ & 2 & $\begin{array}{c}-1.8939 \\
(0.0291)^{*}\end{array}$ & 2 \\
\hline Egypt-Pakistan Exchange Rate & $\begin{array}{c}-3.4769 \\
(0.0003)^{* *}\end{array}$ & 1 & $\begin{array}{c}-2.1267 \\
(0.0167)^{*}\end{array}$ & 1 \\
\hline Egypt-Thailand Exchange Rate & $\begin{array}{c}0.1489 \\
(0.5592)\end{array}$ & 3 & ${ }^{-3.7854}$ & 3 \\
\hline Egypt-U.S.A Exchange Rate & $\begin{array}{c}0.7038 \\
(0.3876)\end{array}$ & 3 & $\begin{array}{c}-1.5785 \\
(0.0455)^{*}\end{array}$ & 3 \\
\hline
\end{tabular}

Symbols * and ** refer to the rejection of the null hypothesis of unit root at the percent of 5 and 1 significance levels, respectively. Values between parentheses are standard error. 


\section{RESULTS AND DISSCUSION}

This section is divided into two parts; the first part concerned with the results from the panel estimation of the Egyptian molasses export demand in the world market that are presented in Tables (3) and (4). The second part concentrates on the results of demand function estimation for each import market separately using ordinary least squares regression.

To decide between fixed or random effects model (FE or RE), a Hausman test has been conducted where thenull hypothesis is that the preferred model is random effects vs. the alternative thefixed effects (Greene, 2003). It mainly tests whether the uniqueerrors are correlated with the explanatory variables; the null hypothesis is they are not. The results of the Hausman test indicate to accept the null hypothesis as the difference in coefficients is not systematic. Thus, the RE is preferred than FE.

Results in Table (3) are the panel estimation of Random Effects Models of factors affecting the export demand quantity of Egyptian molasses. The results indicated that Egypt/Indian price ratio had negative and significant relationship with total export demand of
Egyptian molasses, as one unit decrease in such relative price will lead to increase of the Egyptian molasses export by 686 tons. In contrast, Pakistan and Thailand relative prices were not significant. Coefficient of import country's income was positive and significant ate level 5\% implying that one billion dollar increase corresponds to an increase of import of Egyptian molasses by about 281 tons. This result is consistent with economic logic because increase of the income for import countries lead to increase in their purchasing power. With respect to the relationship between exchange rate and export quantities, the results showed that the higher the Egyptian pound rate to Pakistani Rupee, the lower is the quantity demanded of Egyptian molasses. The negative sign of the estimated parameter was statistically significant at level 5\%. The interrelationship between the exchange rate and nation's competence to export is a complicated issue because of the feedback loop between them. Exchange rate has an impact on the trade balance (surplus or deficit), which sequentially affects the exchange rate. In general, however, depreciation of domestic currency stimulates exports and vice versa.

Table (3): Estimation of random effects model of the demand for Egyptian molasses in the world market

\begin{tabular}{|c|c|c|c|}
\hline Variables & Coef. & $\begin{array}{c}\text { Standard } \\
\text { Error. }\end{array}$ & $\mathbf{Z}$ \\
\hline Intercept & $84454.96^{*}$ & 38349.95 & 2.2 \\
\hline Egypt/Indian price ratio & $-685.94^{* *}$ & 278.23 & -2.57 \\
\hline Egypt/Pakistan price ratio & $481.58^{\mathrm{NS}}$ & 584.84 & 0.82 \\
\hline Egypt/Thailand price ratio & $-348.42^{\mathrm{NS}}$ & 421.23 & -0.83 \\
\hline GDP & $280.87^{*}$ & 14.68 & 1.97 \\
\hline Egypt-Pakistan Exchange rate & $-799.19^{* *}$ & 266.76 & -3.00 \\
\hline Egypt-India Exchange rate & $909.07^{\mathrm{NS}}$ & 672.96 & 1.35 \\
\hline Egypt Thailand Exchange rate & $-508.26^{\mathrm{NS}}$ & 438.48 & -1.16 \\
\hline Egypt/Indian price volatility & $111.45^{\mathrm{NS}}$ & 98.41 & 1.13 \\
\hline Egypt/Pakistan price volatility & $-220.54^{*}$ & 118.92 & -1.95 \\
\hline Egypt/Thailand price volatility & $75.776^{\mathrm{NS}}$ & 149.76 & 0.51 \\
\hline Egypt-Pakistan Exchange rate volatility & $-1525.50^{*}$ & 862.34 & -1.97 \\
\hline Egypt-India Exchange rate volatility & $-433.81^{\mathrm{NS}}$ & 641.64 & -0.68 \\
\hline Egypt Thailand Exchange rate volatility & $-1633.46^{* *}$ & 562.26 & -2.91 \\
\hline $\mathbf{R}^{2}$ within & 0.51 & & \\
\hline $\mathbf{R}^{2}$ between & 0.87 & & \\
\hline $\mathbf{R}^{2}$ overall & 0.61 & & \\
\hline Log likelihood & $-295.96 *$ & & \\
\hline
\end{tabular}

Symbols $*$ and $* *$ refer to the significance of the parameters at the percent of 5 and 1 significance levels, respectively. NS refers to not significant. 
Since the price is the final result of production and consumption, agricultural products are characterized by price volatility due to production and consumption variability. Variability in production may come from weather shocks, planted area, and yield variability. Consumption variability may come from changes in income. Thus, price of agricultural product is very vulnerable. The current concern is that food price volatility may have increased over recent years and may increase further in the future (Gilbert and Morgan, 2010). Accordingly, we investigated the impact of price volatility on Egyptian molasses exports. The results showed that price ratio volatility of Egypt/Pakistan had negative relation with Egyptian molasses export at significance level of 5\% while the volatilities of Indian and Thailand price ratios were not significant. In this context, it is worried that augmented volatility creates uncertainty over future price levels which complicates investment, export, and impedes economic growth.

While it is commonly thought that exchange-rate volatility has negative impact on trade, for instance. Doğanlar (2002) and Cheung and Sengupta (2013), the economic literature has found that this is not always true. Therefore, we investigate the impact of the volatility of exchange rate on Egyptian molasses exports. The results showed that Egypt-Pakistan exchange rate volatility had negative and significant impact at level 5\%, and also Egypt-Thailand exchange rate volatility had negative and significant impact at level $1 \%$. In contrast, the relationship between EgyptIndia exchange rate volatility and Egyptian molasses export was not proved. This result is consistent with Karemera et al. (2015) as the study results confirmed that exchange rate volatility is one of the factors affecting global meat trade.

Since most of volatility variables were not significant, it is sensible to re-estimate the model without volatility variables to avoid specification bias in the estimation through a redundant variable problem and the results are displayed in Table (4). The results in Table (4) are consistent with those in Table (3) in terms of quantity and quality of significant variables. To sum up, Pakistan and India are the most important competitor to Egypt in world market of molasses.

Table (4): Estimation of random effects model without volatility variables

\begin{tabular}{lccc}
\hline Variables & Coef. & $\begin{array}{c}\text { Standard } \\
\text { Error. }\end{array}$ & $\mathbf{Z}$ \\
\hline Intercept & $75671.89^{*}$ & 43306.28 & 1.99 \\
Egypt/Indian price ratio & $-569.60^{*}$ & 294.86 & -1.98 \\
Egypt/Pakistan price ratio & $409.69^{\mathrm{NS}}$ & 658.89 & 0.62 \\
Egypt/Thailand price ratio & $-171.78^{\mathrm{NS}}$ & 465.82 & -0.37 \\
GDP & $216.59^{*}$ & 15.97 & 2.04 \\
Egypt-Pakistan Exchange rate & $-609.49^{*}$ & 276.98 & -2.20 \\
Egypt-India Exchange rate & $429.49^{\mathrm{NS}}$ & 707.79 & 0.61 \\
Egypt Thailand Exchange rate & $-145.99^{\mathrm{NS}}$ & 489.69 & -0.30 \\
\hline $\mathbf{R}^{2}$ within & 0.482 & \\
$\mathbf{R}^{2}$ between & $0.633^{2}$ & $0.42^{2}$ & \\
$\mathbf{R}^{2}$ overall & $-303.71308^{*}$ & \\
\hline Sog likelihood
\end{tabular}

Symbols * and ** refer to the significance of the parameters at the percent of 5 and 1 significance levels, respectively. NS refers to not significant.

With closer insight, three markets had been selected according to Egyptian market share, and import regularity of Egyptian molasses. Fig. (2) displays time series of quantity demanded of Egyptian molasses in destination markets; UK, Italy, and Spain during the period 1986-2012. It is not difficult to note that the time trends of Italian and Spanish market imports are declining while UK market is not. Accordingly, it is necessary to estimate demand function for Egyptian molasses in each individual market. The estimated parameters of suchdemand function are presented in Table (5). The results of UK market showed that the price ratios of India had negative relationship with Egyptian molasses export and significant at level of 1\%. As well as the coefficient of Pakistani price ratio is negative and significant at 5\%. The results of the impact of exchange rate were similar to those of prices. On the other hand, the only significant coefficient of price ratio volatility was for Pakistani price. The Egypt-Pakistan Exchange rate volatility and Egypt-Thailand Exchange rate volatility had have negative signs indicating the inverse relationships between them and Egyptian molasses demand in UK market. 


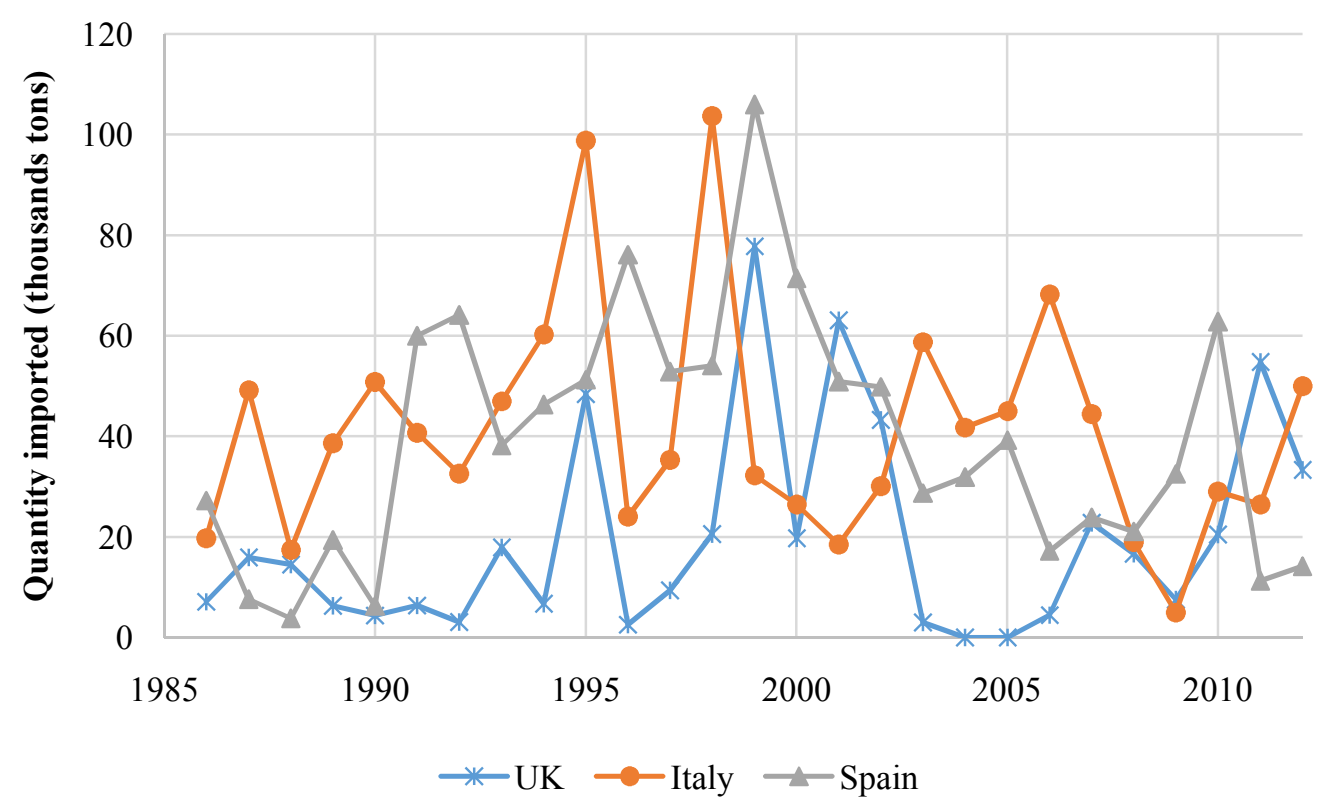

Fig. (2): Exports of Egyptian molasses in selected markets during 1986-2012.

Table (5): Ordinary least squares estimation of export demand function in targeted market.

\begin{tabular}{|c|c|c|c|}
\hline Variables/ Market & UK & Italy & Spain \\
\hline Intercept & $\begin{array}{c}-92882.80 \\
(-0.57)^{\mathrm{NS}}\end{array}$ & $\begin{array}{l}-4446900 \\
(-5.16) * *\end{array}$ & $\begin{array}{c}5391030.00 \\
(0.24)^{\mathrm{NS}}\end{array}$ \\
\hline Egypt/Pakistan price ratio & $\begin{array}{l}-580.88 \\
(-2.81) *\end{array}$ & $\begin{array}{l}1907.34 \\
(1.15)^{\mathrm{NS}}\end{array}$ & $\begin{array}{l}-1458.42 \\
(-2.22) *\end{array}$ \\
\hline Egypt/Indian price ratio & $\begin{array}{c}-299.11 \\
(-4.54) * *\end{array}$ & $\begin{array}{c}-1936.29 \\
(-6.66) * *\end{array}$ & $\begin{array}{c}-1066.48 \\
(-13.88)^{* *}\end{array}$ \\
\hline Egypt/Thailand price ratio & $\begin{array}{c}53.00 \\
(0.07)^{\mathrm{NS}}\end{array}$ & $\begin{array}{l}-234.72 \\
(-2.68) *\end{array}$ & $\begin{array}{l}-589.55 \\
(-2.23) *\end{array}$ \\
\hline GDP & $\begin{array}{c}136.89 \\
(2.98) *\end{array}$ & $\begin{array}{c}5.50 \\
(1.07)^{\mathrm{NS}}\end{array}$ & $\begin{array}{c}11.38 \\
(0.26)^{\mathrm{NS}}\end{array}$ \\
\hline Egypt-Pakistan Exchange rate & $\begin{array}{l}-1459.35 \\
(-2.74) *\end{array}$ & $\begin{array}{l}-1224.00 \\
(-3.18) *\end{array}$ & $\begin{array}{c}54.39 \\
(0.62)^{\mathrm{NS}}\end{array}$ \\
\hline Egypt-India Exchange rate & $\begin{array}{l}-2414.03 \\
(-3.08) * *\end{array}$ & $\begin{array}{l}-387.89 \\
(-1.24)^{\mathrm{NS}}\end{array}$ & $\begin{array}{l}-1513.17 \\
(-4.86) * *\end{array}$ \\
\hline Egypt Thailand Exchange rate & $\begin{array}{l}-1040.43 \\
(-1.88)^{\mathrm{NS}}\end{array}$ & $\begin{array}{c}438.03 \\
(0.93)^{\mathrm{NS}}\end{array}$ & $\begin{array}{c}221.17 \\
(0.07)^{\mathrm{NS}}\end{array}$ \\
\hline Egypt/Pakistan price volatility & $\begin{array}{l}-478.02 \\
(-2.59) *\end{array}$ & $\begin{array}{c}-362.00 \\
(-0.06)^{\mathrm{NS}}\end{array}$ & $\begin{array}{c}-890.27 \\
(-0.27)^{\mathrm{NS}}\end{array}$ \\
\hline Egypt/Indian price volatility & $\begin{array}{c}202.78 \\
(0.99)^{\mathrm{NS}}\end{array}$ & $\begin{array}{c}270.40 \\
(1.42)^{\mathrm{NS}}\end{array}$ & $\begin{array}{l}-340.53 \\
(-3.09) *\end{array}$ \\
\hline Egypt/Thailand price volatility & $\begin{array}{c}356.55 \\
(0.75)^{\mathrm{NS}}\end{array}$ & $\begin{array}{l}-493.37 \\
(-2.48) *\end{array}$ & $\begin{array}{l}-401.88 \\
(-2.41) *\end{array}$ \\
\hline Egypt-Pakistan Exchange rate volatility & $\begin{array}{l}-1688.95 \\
(-4.08) * *\end{array}$ & $\begin{array}{c}678.64 \\
(0.88)^{\mathrm{NS}}\end{array}$ & $\begin{array}{c}259.77 \\
(0.05)^{\mathrm{NS}}\end{array}$ \\
\hline Egypt-India Exchange rate volatility & $\begin{array}{c}-315.65 \\
(-0.30)^{\mathrm{NS}}\end{array}$ & $\begin{array}{c}-248.17 \\
(-0.75)^{\mathrm{NS}}\end{array}$ & $\begin{array}{l}-200.82 \\
(-0.18)^{\mathrm{NS}}\end{array}$ \\
\hline Egypt-Thailand Exchange rate volatility & $\begin{array}{l}-1631.85 \\
(-2.86) *\end{array}$ & $\begin{array}{c}-74.74 \\
(-0.92)^{\mathrm{NS}}\end{array}$ & $\begin{array}{c}1.33 \\
(0.27)^{\mathrm{NS}}\end{array}$ \\
\hline $\mathbf{R}^{2}$ & 0.74 & 0.71 & 0.91 \\
\hline $\mathbf{F}$ & 17.36 & 13.48 & 22.57 \\
\hline D.W & 1.86 & 2.14 & 2.05 \\
\hline
\end{tabular}

Symbols $*$ and $* *$ refer to the significance of the parameters at the percent of 5 and 1 significance levels, respectively. Values between parentheses refer to $t$ student values. NS refers to not significant. 
In Italian market, Price ratios were significant for both Egypt/Indian and Egypt Thailand price ratios at significance level of 5\%. Unusually, Egypt/Pakistani price ratio was not significant. In contrast, exchange rates were not significant except of Egypt-Pakistan which was significant at level $5 \%$. Variables of price ratios volatility were not significant except for Egypt/Thailand ratio which was significant at level 5\%.

In Spanish market, price ratios are considered important factors since Egypt/Pakistan, Egypt/Indian, and Egypt/Thailand price ratios were significant and have negative relation, as expected, with quantity demanded of Egyptian molasses in the Spanish market. Egypt-India exchange rate showed negative and highly significant relation at level of $1 \%$. Volatility variables showed variant relations and significance. Whereas price ratio volatility of Indian and Thailand are negative and significant at $5 \%$, the volatility exchange rate variables are not significant.

The results of goodness fit for each model indicated that the proposed factors explain about $74 \%$, $71 \%$, and $91 \%$ of the total variance of Egyptian molasses exports in UK, Italy, and Spain market, respectively. The results of Durbin Watson test fortunately indicated that there is no auto-serial correlations.

To measure the responsiveness of Egyptian molasses exports to UK, Italy, and Spain Markets to the price ratios, the price ratios elasticities in each market were calculated in Table (6). The results showed that the highest responses of Egyptian molasses exports to Egypt/Pakistan price ratios were in UK and Spain markets reflecting the sever competition between Egyptian and Pakistani molasses in these markets. Consequently, results suggested that $1 \%$ increase in such price ratio may led to a decrease in Egyptian molasses to UK and Spain markets by $4.85 \%$ and $4.12 \%$, respectively.

Moreover, the sensitivity of Egyptian exports of molasses to Egypt/India price ratios was highest in Italy market by $5.01 \%$ followed by in UK market by $1.75 \%$. Conversely, the responsiveness to the Egypt/Thailand price ratios were not as those to Egypt/Pakistan and Egypt/Indian price ratios as they were $0.64 \%$ and $1.53 \%$ in Italy and Spain Markets respectively.

$\underline{\text { Table (6): Demand price ratios elasticities for Egyptian molasses in selected markets. }}$

\begin{tabular}{lcccccc}
\hline \multirow{2}{*}{$\begin{array}{c}\text { Price Ratio } \\
\text { Ek }\end{array}$} & Average & Elasticity & Average & Elasticity & Average & Elasticity \\
\hline Egypt/ Pakistan & 1.73 & -4.85 & 1.03 & NS & 1.13 & -4.12 \\
Egypt/India & 1.21 & -1.75 & 1.05 & -5.01 & 1.09 & NS \\
Egypt/Thailand & 2.07 & NS & 1.12 & -0.64 & 1.06 & -1.53 \\
\hline
\end{tabular}

Note: NS refers to not significant according to the estimated parameters in Table (4).

\section{REFERENCES}

Akhtar, M. A. and R. S. Hilton (1984). Exchange rate uncertainty and international trade: Some conceptual issues and new estimates for Germany and the United States.

Al-Santarisi, M. (1995). The future of Egyptian agriculture in international trade. Options Mediterraneennes. Serie B: Etudes et Recherches (CIHEAM).

Alboghdady, M. A. (2007). Analysis of Egyptian groundnuts market shares in the world market. Egyptian Journal of Agricultural Economics, 17: $1264-1273$

Asseery, A. and D. A. Peel (1991). The effects of exchange rate volatility on exports: some new estimates. Economics Letters, 37: 173-177.

Bassyouni, G. (2009). An economic study for Egyptian foreign agricultural trade with emphases on relationship with European Union. In: The Second International Conference on Economical Competitiveness, Quality of Life, and Sustainability, pp. 68-79. kaposvár University, Hungary.
Breitung, J. and S. Das (2005). Panel unit root tests under cross-sectional dependence. Statistica Neerlandica, 59: 414-433.

Cheung, Y.-W. and R. Sengupta (2013). Impact of exchange rate movements on exports: an analysis of Indian non-financial sector firms. Journal of International Money and Finance, 39: 231-245.

Choi, I. (2001). Unit root tests for panel data. Journal of International Money and Finance, 20: 249-272.

Chowdhury, A. R. (1993). Does exchange rate volatility depress trade flows? Evidence from errorcorrection models. The Review of Economics and Statistics, 700-706.

Cushman, D. O. (1983). The effects of real exchange rate risk on international trade. Journal of International Economics, 15: 45-63.

Doğanlar, M. (2002). Estimating the impact of exchange rate volatility on exports: evidence from Asian countries. Applied Economics Letters, 9: 859863.

Gilbert, C. L. and C. W. Morgan (2010). Food price volatility. Philosophical Transactions of the 
Royal Society of London B: Biological Sciences, 365: 3023-3034.

Goldstein, M. and M. S. Khan (1978). The supply and demand for exports: a simultaneous approach. The Review of Economics and Statistics, 275286.

Greene, W. H. (2003). Econometric analysis. Pearson Education India.

Hooper, P. and S. W. Kohlhagen (1978). The effect of exchange rate uncertainty on the prices and volume of international trade. Journal of International Economics, 8: 483-511.

Im, K. S., M. H. Pesaran and Y. Shin (2003). Testing for unit roots in heterogeneous panels. Journal of Econometrics, 115: 53-74.

Jin, H. J. (2010). The effects of competition on U.S. wheat market shares in East Asia. Journal of Economic Development, 35: 37-55.

Karemera, D., W. Koo, G. Smalls and L. Whiteside (2015). Trade creation and diversion effects and exchange rate volatility in the global meat trade. Journal of Economic Integration, 30: 240-268.
Kenen, P. B. and D. Rodrik (1986). Measuring and analyzing the effects of short-term volatility in real exchange rates. The Review of Economics and Statistics, 311-315.

Kheir-El-Din, H. (2008). The Egyptian economy: Current challenges and future prospects. American Univ in Cairo Press.

Koray, F. and W. D. Lastrapes (1989). Real exchange rate volatility and U.S. bilateral trade: A var approach. The Review of Economics and Statistics, 71: 708-712.

Levin, A., C.-F. Lin and C.-S. J. Chu (2002). Unit root tests in panel data: asymptotic and finitesample properties. Journal of Econometrics, 108: 1-24.

Serenis, D. and N. Tsounis (2012). A new approach for measuring volatility of the exchange rate. Procedia Economics and Finance, 1: 374-382.

World-Bank (2001). Egypt - toward agricultural competitiveness in the $21^{\text {st }}$ century - an agricultural export-oriented strategy. World Bank, Washington, DC: World Bank.

\section{الطلب على العسل الأسود المصري في السوق العالمي: تقدير قطاعي - زمني

\author{
محمد التابعي علي البغدادي

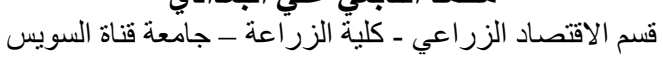

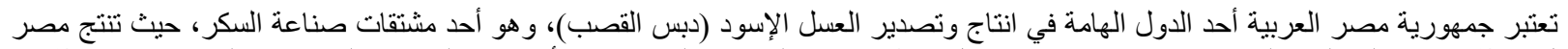

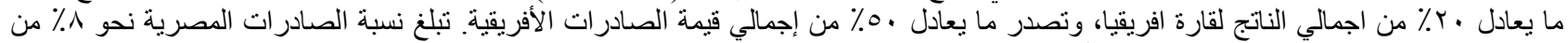

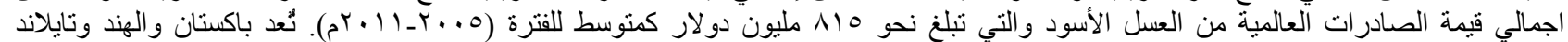

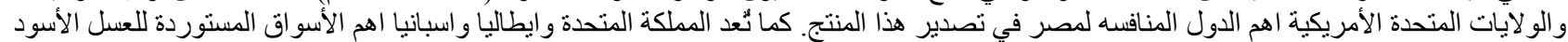

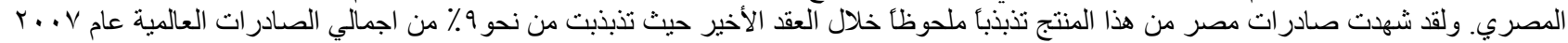

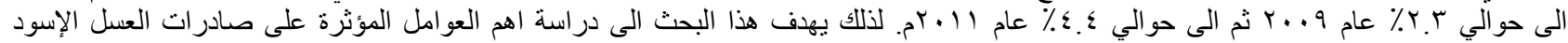

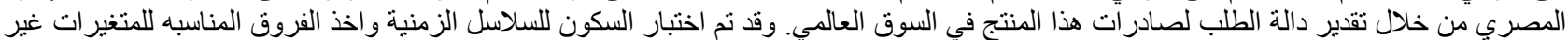

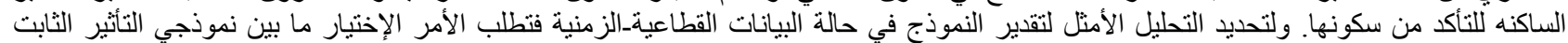
(Fixed Effect Model)

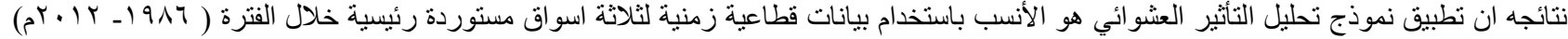

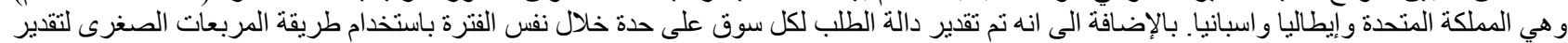
معالم الإنحدار المتعدد.

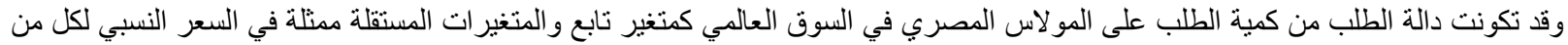

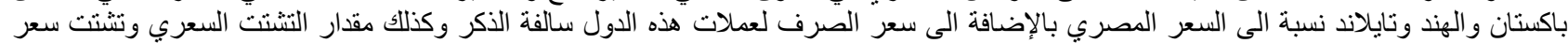

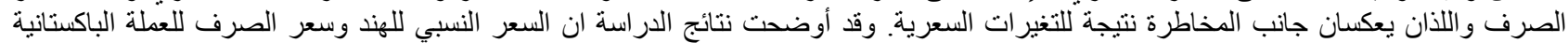

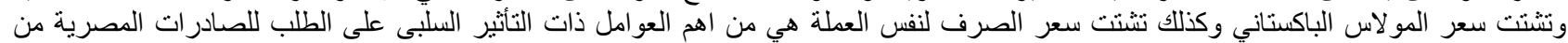

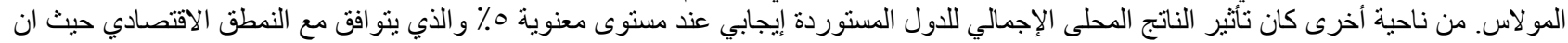

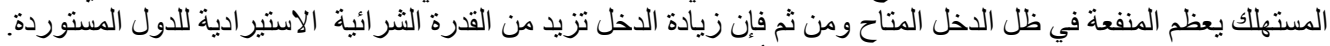

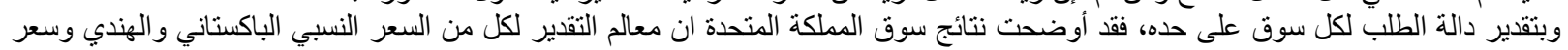

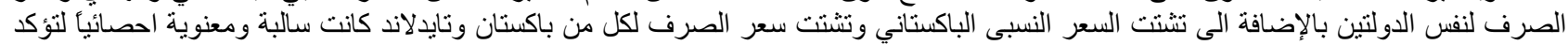

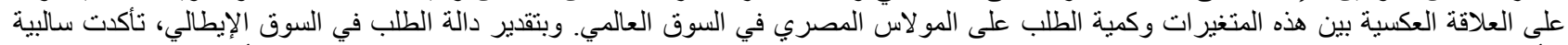

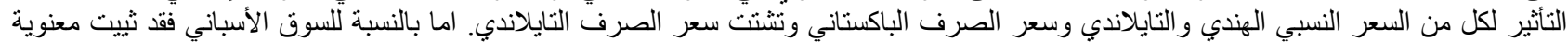

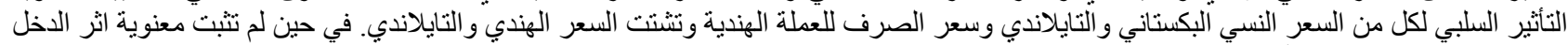
لكل من السوق الإيطالي و الأسباني.

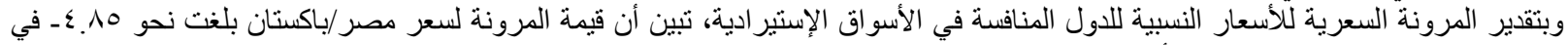

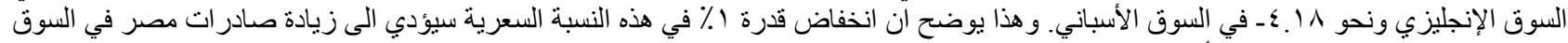

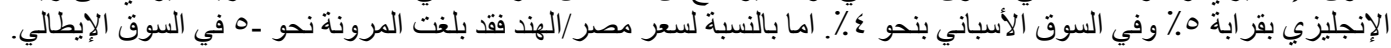

